\title{
Evaluating the Impact of Customer Relationship Management (CRM) Strategies on Customer Retention (A Study of Fast Food Chains in Pakistan)
}

\author{
Rao Tahir Anees (Corresponding Author)
}

Post Graduate Centre, Limkokwing University of Creative Technology, Cyberjaya, Malaysia

Tel: +60 1151856795

E-mail: aneesrao82@gmail.com

\author{
Nordiana Ahmad Nordin (Co-author) \\ Faculty of Economics and Business, University Malaysia, Sarawak, Malaysia \\ Tel: +60138101801 \\ E-mail: annordiana@unimas.my
}

Temoor Anjum (Co-author)

Post Graduate Centre, Limkokwing University of Creative Technology, Cyberjaya, Malaysia Tel: +601123158557

E-mail: tamooranjum@yahoo.com

\author{
Luigi Pio Leonardo Cavaliere (Co-author) \\ Dipartimento di Economia, Università di Foggia, Foggia, Italy \\ Tel: +393895739195 \\ E-mail: luigi.cavalie@gmail.com
}

Petra Heidler (Co-author)

Department of International Business and Export Management, IMC University of Applied Sciences, Krems, Austria 
Tel: +436643000301

E-mail: petra.heidler@fh-krems.ac.at

Received: October 19, 2020 Accepted: November 11, 2020 Published: November 13, 2020

doi:10.5296/bms.v11i2.17934

URL: https://doi.org/10.5296/bms.v11i2.17934

\begin{abstract}
Customer focus is a concept that academics and professionals have been discussing in recent years. These are deeply ingrained ideas and standards that make customer relationships a top priority within the organization. The main objective of this research is to determine the impact of the CRM strategy on customer retention. The total sample of this study is 220, and the questionnaire includes 15 items. This research is based on exploratory and quantitative nature. Use survey methods to collect data from respondents through questionnaires. Calculate SmartPLS-SEM-3.0 to study the hypothesis of this investigation. The findings of this research show that Customer Orientation and Service Quality have an impact on Customer Retention. Additionally, the sale of a company can increases if they are maintaining the quality of the food, and there will be significantly less Customer Retention.
\end{abstract}

Keywords: Customer Relationship Management, Customer Retention, Service Quality, Fast Food Chain

\title{
1. Introduction
}

Customer Relationship Management (CRM) is a concept often used to track the relationship of an organization with vendors, clients, and business opportunities. It requires any use of technologies for business operations to be organized, streamlined, and synchronized, and improving productivity, revenue, and customer loyalty is the target of CRM (Lambert \& Enz, 2016). Service providers have used a range of tools, techniques, and processes to optimize client relationships to increase sales to enforce CRM. CRM would seem to be a significant concern with the market and operations, not a technological challenge (Babu, 2016).

Customers need to have more facilities in today's retail climate and anticipate businesses to offer more products and services. Companies should consider consumers' needs and desires and buy behaviour; develop and manage experiences to build the optimal experience for customers (Nazar, Ramzani and, Temoor Anjum, 2018a). The company's overall aim would be to use technology and CRM principles to generate customer loyalty. In terms of making their staff very customer-focused and welcoming, companies are gradually developing their internal customer retention strategies (Al-weshah, Al-manasrah, and Al-qatawneh, 2018). Currently, in a fiercely competitive environment (Nazar, Jahan, Amoozegar, Anjum, and Raju, 2020), the company is nevertheless dedicated to satisfying consumer needs and seeking to do 
that more efficiently than rivals.

The overview of its CRM approach is built on the presumption that customers are now the company's most valuable objects but also that the firm needs to maintain prudent customer engagement (Islamgaleyev, Petrova, Kurenkeyeva, Shalabayeva and Kadirbergenova, 2020). The implementation of a dedicated data retrieval mechanism would enable quick data utilization and a centralized system for managing customer experience and even the best customer support. The support to CRM throughout the communications, delivery, and operations domains, improvements are also required ( $\mathrm{Ng}$, Sweeney \& Plewa, 2020). In many other terms, CRM is also a useful technique that enables consumers to improve their goods, retain and acquire new customers across different communication channels (Valens, Grace and Alphonse, 2020).

\section{Literature Review}

Customers require immense skill and awareness of various restaurant practices, and rising food demand is growing. The fast-food is becoming incredibly misguided, leading suppliers to introduce effective advertising strategies to achieve comparative advantages and broaden their understanding of consumer needs (Filimonau Y Krivcova, 2017). So, several fast-food restaurants are already contributing to studying, analyzing, and developing marketing campaigns to capture the largest market share of customers and gain customer retention and loyalty to boost the organization's financial efficiency. Through restaurant management, customer service is crucial even though it is favourably perceived as either a significant determinant of a regular customer, consumer engagement, and awareness of word of mouth (Rao, Raju, \& Anjum, 2020). The higher the customer's satisfaction, the higher the retention. The effect of customer satisfaction on customer retention is incredible and motivating (Rather and Sharma, 2017).

As per multiple earlier kinds of research (Cateng, 2016; Shanmugasundaram and Srilekha, 2017), using that CRM component is valuable for insurance firms and customers. To maintain the competitive advantage of insurance companies, clients must remain in the insurance department. Compared to customer acquisition, customer retention is more critical to organizations in the insurance industry. Customer retention is assessed using CRM dimensions, including the efficiency of insurance organizations, the right word of mouth, loyalty to insurance companies, and repeated purchase intentions (Xing \& Devasia, 2019).

\subsection{Customer Relationship Management and Strategies}

The concept of CRM strategy refers to the practice of focusing on turning each potential customer into a customer and keeping customers through personalized communication with them. The idea of CRM has made organizations enhance communication with clients ever since implementation and reach their objectives (Mau, Pletikosa, Wagner and Mau, 2018). CRM's fundamental aim is to strengthen customer retention and satisfaction by adequately analyzing customer knowledge, thereby trying to improve the firm's global corporate competitiveness (Garrido-moreno and Padilla-meléndez, 2011). The company's primary goal 
is to gain and retain customers. By trying to adopt the appropriate CRM strategy that synchronizes the company's personnel, mechanisms and technological aspects, such an assumption could be gained (Drucker, 1985). Two key indicators, namely: many scholars define customer relationship management and orientation, which describe the successful implementation of CRM strategies, and conclude that customer engagement and retention in CRM are significant indicators (Jin et al., 2020).

A strong customer relationship would help you in achieving higher retention and loyalty. Corporate approaches that seek to reduce costs by optimizing customer retention are Customer Relationship Management (CRM) processes (Boadu, Kankam, 2019). To allow insurance companies to start engaging in customer-oriented behaviour, CRM companies demonstrate a high standard of customer engagement. Adopting modern technology, the CRM organization conducts efficient communication and customer engagement. It suggests that CRM businesses have a strong bond with both the insurance industry's consumer retention (Boateng, Rahman, Feeh \& Anning-dorson, 2016; Hardjono \& San, 2017).

CRM companies, however, allow insurance companies to achieve the objective of maintaining a fair and sustainable partnership between the insurer and its customers (Hardjono \& San, 2017). CRM is named the dynamic and integrated framework. Industry processes and the structure of technology are associated with improving customer satisfaction and loyalty by building strong relationships of confidence and dedication amongst customers and staff, thereby supporting the company's growth. In such a highly competitive environment, CRM practices that will help banks retain established customers (Thaichon, Liyanaarachchi, Quach, and Weaven, 2019). Comprehensive CRM will influence customer satisfaction and increase the retention of customers. CRM has quite a positive effect on banks' productivity, profitability and effectiveness, but bank fraud must also be detected (Ngetich, 2018).

An organization focused on clients, information management, CRM technology and CRM. All such facets have a significant effect on customer retention rate and growth of sales volume (Chetioui, Abbar and Benabbou, 2017). Several other studies have concluded that the long-term relationship among both customers and banking organizations can be continued to improve when service members are much more customer-focused (Hafeez \& Basheer, 2018). Customer-oriented service staff have a higher understanding of the tasks, can acknowledge customer needs and wants virtually, and therefore can appropriately fulfil them. Both consumers continue to extend their associations with companies and concentrate on customer loyalty services that have a positive effect on the improvement and retention of customers (Qi, Wang, \& Koerber, 2020; Thaichon, etc., 2019).

\subsection{Customer Orientation and Customer Retention}

The main item of the service organization is the long-term interaction between service personnel and customers. The relationship between service personnel and customers and the experience they have acquired (for example, those who cannot provide services in a pleasant 
manner or those who lack sufficient knowledge and training to meet customer expectations) can affect to the clients. Memory negatively affects the quality of service (Rouholamini and Alizadeh, 2016). Therefore, service personnel are the primary resources with which service companies can use their competitive advantages. Although they enjoy the ability to cross borders in the workplace, they also increase their impact (Torabi \& El-Den, 2017).

In order to spread positive news about service providers, several reports have already shown that happy customers prefer word of mouth communications strategy. Other research shows that perhaps the company's long-term clients will make further orders. Loyal customers will become more open, usually paying and creating demand, towards purchasing any form of firm goods and services, and the cost of the product will also be lower. Ultimately, buyers would not be excessively price-sensitive because the profitability is the income of the business. The higher labour knowledge of customer-oriented service staff can accurately recognize the customer's needs and wants and fulfil their expectations in a satisfactory manner (Bruhn, 2020; González Porras, JL, Ruiz-Alba, JL and Guzmán Parra, 2018).

Keeping a strong customer orientation is critical in creating a brand for a specific product or service in today's intensely competitive environment. The brand is closely associated with purchasing behaviour and consumer responses to goods or services (Rahi, 2016). In terms of distribution, promotion, operation and services activities inside the organization, the customer-oriented management approach handles the connection between both the insurance companies and its customers. Customer orientation is indeed a mechanism for insurance companies to acquire, establish and retain relationships with customers, allowing them to improve profitable customer retention rates (Lehrer et al., 2018). Consumer-oriented restaurant workers have a high degree of job knowledge, can easily recognize customer expectations and desires, and can efficiently meet them. Each customer continues to extend their relationships with organizations and focus on services of customer loyalty that have a positive effect on customer retention and engagement growth (Alzaydi, Al-hajla, Nguyen \& Jayawardhena, 2018).

Orientation has a strong effect on the retention of customers. The author exposes two essential results: First, since they like customer-centric personnel, consumers are likely to return to customer-centric service provider businesses. Second, customers would be more impacted by restaurant employees who will represent this confidence throughout the business. Furthermore, the author compares customer satisfaction, commitment, and retention with the customer orientation of restaurant employees (Moghadam, 2013). A critical component in the quality of design process is the development of acceptable behavior, values and beliefs in businesses which provide product or service that customers need or want, which can establish an influential role for customers / understand customer needs and expectations (Cheow, Yeo, Goh and Rezaei, 2017; Kanwal et al., 2020).

The term "customer-oriented" means that service personnel must clearly understand the customer's needs. Service personnel must also match their behavior to meet the needs of customers in the service organization. The customer orientation of service personnel has been 
viewed as the relationship between the customer and the service organization. Therefore, service personnel must find the best conditions for customers, rather than selling quickly and making short-term profits. Whether the client is satisfied with the service received depends on the service received (Ikhsan, 2016). Generally, satisfaction refers to a customer's performance that is pleasant or unpleasant compared to their expectations. According to this clear definition, satisfaction depends on psychological performance and expectations. If the performance of a service is lower than expected, the customer will be dissatisfied. At the same time, if the performance of a service is the same as expected, the customer will be satisfied,

\subsection{Service Quality and Customer Retention}

Service quality is defined to be a core aspect of modern service companies' sustainability. The concept of service quality and the nearly quantitative customer satisfaction relationship allow itself an important promotional technique, allowing this the most examined marketing field of service (Suraj, 2016). There is a clear significant connection among the quality of service dimensions (tangible, reliable, responsive and guaranteed) and consumers' willingness to come back. This has also been noticed that enhancing service quality has a substantial effect on customer satisfaction (Mady, 2020). Influence customer intention by examining the series of retention activities from both the point of view of customer service and customer satisfaction. Our findings indicate that the greater the standard of service, the greater the retention rate of customers (Miao, Zhang, Wu, Zhang Hejiang, 2019).

The influence of the mobile phone company's service quality on the customer retention rate, and found that the service quality and customer retention rate have a positive and significant relationship. In the restaurant market, it shows that the quality of food is also one of the most common attributes in the quality of service and the quality atmosphere of the restaurant (Bilgihan \& Bujisic, 2014). It can even be noticed that these variables have quite a favourable influence on consumer behavioural intentions (like return intentions and word of mouth reviews). There are usually two foreseeable consequences that demonstrate the importance of the competitiveness of service quality. Second, the standard of service can be seen among the few types of differentiated services and competitive advantage, which can bring new clients and sales volume. Secondly, service quality is considered an effective means of customer retention (Bratman, Hamilton and Daily, 2012).

Whenever clients select a retailer that offers a service quality that meets or exceeds certain expectations, they are much more willing to choose the same retailer afterwards. As an indicator of customer retention, behavioural intent is mostly used, that also requires looking at customer retention from a transactional perspective (Nazar et al., 2020). The intention of the individual to leave or remain for an extended period; however, it is not very pleasant. Long-term retention of customers and long-term customer relationships obtain many significant advantages. The quality of interaction between two sides can be defined through time, and performance can be increased. In other phrases, at such a lesser cost, a better quality can be delivered. The suggested system has also been included in the service quality 


\section{Macrothink

literature. The researchers stated that service quality would not only influence future business activities but also will facilitate long-term customer relationship development and survival (Liljander, Roos, Liljander \& Roos, 2002; Yeh et al., 2017).

It is possible to define the customer retention rate as the likelihood that the company would retain customers. Also, it is assumed that customer retention is a lifetime opportunity to continue them (Rakthin, Calantone \& Feng, 2016). For every organization, the value, including its life cycle of the client, can be calculated by its financial output. Several studies have analyzed keeping users from a behavioural point of view. Customers, therefore, clearly relate to the business and have dedicated themselves to that as well (Umashankar, Bhagwat and Kumar, 2016).

The level of competition has risen and, growing to low quality, the critical gaps in goods and services are also limited in the industry. This leads to lower retention rates for consumers and increased labour costs (Al-mashraie, Hoon, and Woo, 2020). The retention function is controlled as the end of a fiscal year when consumer engagement reaches the end this year to see how many consumers are doing business with a company due to low quality. Customer dismissal reflects the retention rate of the customer, and that only the customer with the challenging thing interest in the market is the primary retention target (Adly \& El, 2019).

CRM is becoming a great tool and a modern way for goods and services to be included. CRM has now become a strategic necessity for companies in all industrial sectors (Shapiro, 2019). The business makes touch with consumers, puts more time and effort into finding new ways to generate value for customers, and turns consumer relationships instead of sales and deliveries into pursuing solutions and cooperation (Singh et al., 2019).

\section{Conceptual Framework}

A research framework has been designed and illustrated in Figure 1.

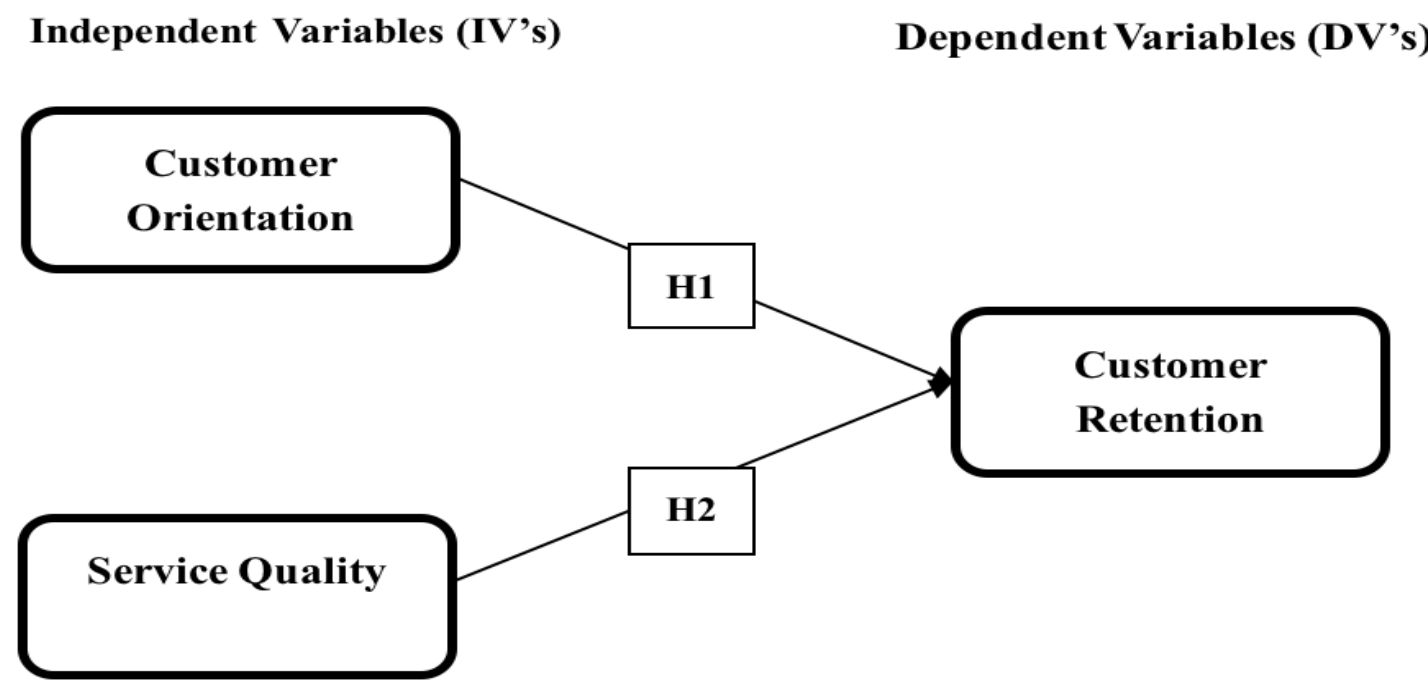

Figure 1. Research Framework 


\section{Hypothesis}

Based on the above Literature and Model, the following two hypotheses are developed.

- H1: Customer orientation has a significant and positive impact on customer retention.

- H2: Service quality has a significant and positive impact on customer retention.

\section{Research Methodology}

The data were collected from fast-food chain customers (McDonald's, KFC, Sasha Cafe) in Lahore, Pakistan. This study selected a specific fast-food chain because it was the first to adopt CRM in Lahore. A simple random sampling technique was used to collect data on the total number of McDonald's, KFC, and Sasha customers. The total sample of this study is 220, and the questionnaire includes 15 items. Before collecting the final data, a pilot study was carried out on 25 customers to make sure the validity of the face and the content of the survey.

The nature of the study is an exploratory study and a survey conducted to examine the relationship with customers in Lahore, Pakistan and the retention rate of customers in the food chain (McDonald's, KFC, Sasha Cafe). Quantitative analysis methods generally include extensive randomized investigations, more methodological analyzes, and fewer case checks. The questionnaire was distributed in two ways, including hardcopy and softcopy formats. The printed version of the questionnaire was sent via e-mail, and the printed version was distributed separately. The five-point Likert Scale was used in measuring the items which ranged from 1 to 5, 1 standing for strongly disagree, and five standing for strongly agree. Measurement and structural models were utilized to test the hypothesis by computing Smart PLS-SEM-3 (Anjum, Amoozegar, Nazar, \& Kanwal, 2020; Anjum, Ramzani, et al., 2018; Anjum, Sharifi, Nazar, \& Farrukh, 2018).

\section{Findings}

Table 6.1 Demographic statistics table presents the frequency and the percentage of the demographic characteristics of the respondents. The features examined were the gender, age, occupation and visits of the respondents. 
Table 6.1 Demographic Statistics

\begin{tabular}{|c|c|c|c|c|}
\hline & & Frequency & Percent & $\begin{array}{l}\text { Cumulative } \\
\text { Percent }\end{array}$ \\
\hline & Male & 172 & 78.18 & 78.18 \\
\hline Gender & Female & 48 & 21.82 & 100 \\
\hline & Total & 220 & 100 & \\
\hline & 20-30 years & 60 & 27.27 & 27.27 \\
\hline & 31-40 Years & 31 & 14.09 & 41.36 \\
\hline Age & 41-50 Years & 64 & 29.09 & 70.45 \\
\hline & $\begin{array}{l}51 \text { years and } \\
\text { above }\end{array}$ & 65 & 29.55 & 100 \\
\hline & Total & 220 & 100 & \\
\hline & Student & 31 & 14.09 & 14.09 \\
\hline & Working & 78 & 35.46 & 49.55 \\
\hline Occupation & Unemployed & 97 & 44.09 & 93.64 \\
\hline & Other & 14 & 6.36 & 100 \\
\hline & Never & 32 & 14.55 & 14.55 \\
\hline & Once a Week & 84 & 38.18 & 52.73 \\
\hline $\begin{array}{l}\text { How Often } \\
\text { Visit }\end{array}$ & $\begin{array}{ll}2-4 \text { Times a } \\
\text { week }\end{array}$ & 72 & 32.73 & 84.46 \\
\hline & Once a Month & 21 & 9.54 & 95.00 \\
\hline & Everyday & 11 & 5.00 & .100 \\
\hline & Total & & & \\
\hline
\end{tabular}

\subsection{Descriptive Statistics}

The descriptive analysis was used to investigate the average value of the measurement scale of the study. In this study, five points Likert scale was used to determine the response of the participants. Hence, 2.5 are suggested the average value of the scale. In this study, all the variables indicate the mean value more than cut score 2.5 ; it demonstrates that all the variables are moderate. The findings are shown in Table 6.2 Descriptive Statistics.

Table 6.2 Descriptive Statistics

\begin{tabular}{lll}
\hline Constructs & Mean & Std. Deviation \\
\hline Service Quality & 3.49 & 1.25 \\
Customer Orientation & 3.35 & 1.29 \\
Customer Retention & 3.28 & 1.11 \\
\hline
\end{tabular}

\subsection{Measurement Model Assessment}

The measurement model must be evaluated by verifying the reliability of internal consistency 
(ICR), convergence validity (CV) and discriminant validity (DV) (Chin, 1998; Hair Jr, Hult, Ringle \& Sarstedt, 2017). The results showed that all the constructs' CR scores exceeded the standard threshold of 0.7 , indicating that the scale used in this study has a high internal consistency. Next, the factor load and the mean-variance extracted (AVE) are evaluated to determine the $\mathrm{CV}$ of the construct. $\mathrm{CV}$ is "the degree to which a measure is positively correlated with alternative measures of the same structure" (Hair Jr et al., 2017). The factor loading must be 0.708 or more, and 0.70 is considered close enough to be acceptable (Hair $\mathrm{Jr}$ et al., 2017). However, if other indicators have higher loadings, the indicators with weaker factor loadings (i.e. 0.40 to 0.70 ) can be preserved, and the overall structure should explain at least $50 \%$ of the difference (Hair Jr et al., 2017). The AVE score of all constructs also exceeded the threshold of 0.5 , indicating a good $\mathrm{CV}$.

Table 6.3 Composite Reliability

\begin{tabular}{lllll}
\hline Constructs & Indicators & Loading & Reliability & AVE \\
\hline Customer Orientation & CO1 & .743 & .887 & .659 \\
& CO2 & .750 & & \\
CO3 & .758 & & \\
Service Quality & CO4 & .791 & & \\
& CO5 & .789 & & .661 \\
& SQ1 & .782 & .236 & \\
Customer Retention & SQ2 & .771 & & \\
& SQ3 & .885 & \\
& SQ4 & .886 & & \\
& SQ5 & .792 & & \\
& CR1 & .888 & .881 & \\
& CR2 & .875 & & \\
& CR3 & .784 & & \\
& CR4 & .786 & & \\
& CR5 & .798 & & \\
\hline
\end{tabular}

As shown in Table 6.4 below, compare the correlation between potential constructs with the square root of the average variance extracted (Fornell, C., \& Larcker, 1981). Furthermore, it shows that each square root of the average variance extracted exceeds the correlation between the underlying constructs. So, this indicates that enough DV has been achieved.

Table 6.4 Fornell and Larcker's Assessment

\begin{tabular}{|l|l|l|l|}
\hline Constructs & $\begin{array}{l}\text { Customer } \\
\text { Orientation }\end{array}$ & $\begin{array}{l}\text { Service } \\
\text { Quality }\end{array}$ & $\begin{array}{l}\text { Customer } \\
\text { Retention }\end{array}$ \\
\hline Customer Orientation & .811 & & \\
\hline Service Quality & .432 & .813 & \\
\hline Customer Retention & .443 & .479 & .796 \\
\hline
\end{tabular}




\subsection{Structural Model Assessment}

The structure model assessment is used to evaluate the relationship among the latent constructs and check the strength of the conceptual model (Hair Jr et al., 2017). For this concern, the direct (path coefficient) effect was investigated between the constructs. It is best to source for examining the multi-correlation constructs. Additionally, t-value should be greater than 1.69 and p-value that should be less than .05 (Henseler, Ringle, \& Sinkovics, 2009).

Table 6.5 Path Coefficients

\begin{tabular}{llllll}
\hline \multicolumn{2}{l}{ Hypothesis } & Beta & T & P & Decision \\
\hline H1 & $\begin{array}{l}\text { Customer orientation has a significant and } \\
\text { positive impact on customer retention. }\end{array}$ & 3.18 & $.00 *$ & Accepted \\
H2 & $\begin{array}{l}\text { Service quality has a significant and positive } \\
\text { impact on customer retention. }\end{array}$ & 0.29 & 2.98 & $.01 *$ & Accepted \\
\hline
\end{tabular}

\subsection{Coefficients of Determination ( $R 2)$}

The examination of the (R2) of the endogenous latent variables based on the threshold of acceptable values of $\mathrm{R} 2$ is $0.19,0.33$, and 0.67 indicated weak, moderate, and strong, respectively (Chin, 1998; Henseler et al., 2009).

Table 6.6 Coefficients of Determination $\left(\mathrm{R}^{2}\right)$

\begin{tabular}{lcl}
\hline Variables & $\mathbf{R}^{\mathbf{2}}$ & Range \\
\hline Customer Retention & .57 & Moderate \\
\hline
\end{tabular}

The test of R2 overall impact of the model also shows that a moderator influence on customer retention.

\section{Discussion}

The results show that the customer-oriented CRM strategy and service quality are considered independent variables, while the "customer retention" is regarded as a dependent variable. There is a positive correlation between these variables and this connection is significant. It can be seen that there is a correlation between "customer orientation and quality of service" and "customer retention", so "customer orientation and service quality" has a very positive relationship with customer retention. These two hypotheses were tested to understand if there are significant differences in the subdivided food industry's service quality levels. The results also show that the quality of service is more customer-oriented. Most importantly, only when the customer is satisfied will the customer retention rate increase, and the customer purchase frequency and retention rate will also increase.

\section{Conclusion}

The results show that excellent customer-oriented advertising and service capability will 
satisfy customers and improve customer satisfaction. In general, the level of customer orientation of the three fast-food chains is very high, and they are considered to have a high level of customer orientation. The relatively high retention level in the food chain category indicates the strong connection between the customer and the food and the possibility that the customer will not transfer or change the taste. In all types, customers think that the service price is satisfactory, reasonable, and the quantity of food is high. Finally, on the subject of the relationship between customer-oriented practices and customer retention, it can be concluded that there is a moderate and positive relationship between customer-oriented practices and customer retention throughout the food chain. Satisfied customers will come back to buy the company's products without hesitation. Restaurants may also conduct investigations through complaint and suggestion boxes or direct customer surveys after providing services. For future research, other variables (such as customer loyalty) can be added as variables. Additionally, the sample size needs to be increased so that it is not limited to a single fast-food company. However, it can also be obtained at various other restaurants. The results of this study do not provide a general picture retained by customers in the food industry. The temporary impact involved in the investigation period is limited. This research only studies the customer retention rate in the food industry, and the analysis exclusively focuses on fast food chains in Lahore, Pakistan.

\section{References}

Adly, S., \& El, H. (2019). How Engaged Customers Can Help the Brand: An Empirical Case Study on a Higher Education Institution ( University ) in Egypt. International Journal of Marketing Studies, 11(1), 85-99. https://doi.org/10.5539/ijms.v11n1p85

Al-mashraie, M., Hoon, S., \& Woo, H. (2020). Customer switching behavior analysis in the telecommunication industry via push-pull-mooring framework: A machine learning approach. $\begin{array}{llll}\text { Computers \& Industrial Engineering, } & \text { 144(April), } & 106476 .\end{array}$ https://doi.org/10.1016/j.cie.2020.106476

Al-weshah, G. A., Al-manasrah, E., \& Al-qatawneh, M. (2018). Customer relationship management systems and organizational performance: Quantitative evidence from the Jordanian telecommunication industry. Journal of Marketing Communications, 7266, 1-21. https://doi.org/10.1080/13527266.2018.1449007

Alzaydi, Z. M., Al-hajla, A., Nguyen, B., \& Jayawardhena, C. (2018). A review of service quality and service delivery. Service Quality and Service Delivery, 24(1). https://doi.org/10.1108/BPMJ-09-2016-0185

Anjum, T., Amoozegar, A., Nazar, N., \& Kanwal, N. (2020). Intervening effect of attitudes towards entrepreneurship: Correlation between passion and entrepreneurial intention. International Journal of Advanced Science and Technology, 29(5 Special Issue), 1327-1340.

Anjum, T., Ramzani, S. R., Farrukh, M., Raju, V., Nazar, N., \& Shahzad, I. A. (2018). Entrepreneurial Intentions of Pakistani Students: The Role of Entrepreneurial Education, 
Creativity Disposition, Invention Passion \& Passion for Founding. Journal of Management Research, 10(3), 76. https://doi.org/10.5296/jmr.v10i3.13253

Anjum, T., Sharifi, S., Nazar, N., \& Farrukh, M. (2018). Determinants of Entrepreneurial Intention in Perspective of Theory of Planned Behaviour. Management Theory and Studies for Rural Business and Infrastructure Development, 40(4), 429-441. https://doi.org/10.15544/mts.2018.40

Babu, G. C. (2016). The Evolution of Customer Opportunities and Challenges . Relationship Management (CRM), 7(8), 43-58.

Bilgihan, A., \& Bujisic, M. (2014). Electronic Commerce Research and Applications The effect of website features in online relationship marketing: A case of online hotel booking. ELECTRONIC COMMERCE RESEARCH AND APPLICATIONS, 1-11. https://doi.org/10.1016/j.elerap.2014.09.001

Boadu, Kankam, and A. A. (2019). Customer Relationship Management and Customer Retention. Customer Relationship Management and Customer Retention. https://doi.org/10.2139/ssrn.3472492

Boateng, H., Rahman, D., Feehi, A., \& Anning-dorson, T. (2016). Computers in Human Behavior Assessing the determinants of internet banking adoption intentions: A social cognitive theory perspective. Computers in Human Behavior, 65, 468-478. https://doi.org/10.1016/j.chb.2016.09.017

Bratman, G. N., Hamilton, J. P., \& Daily, G. C. (2012). The impacts of nature experience on human cognitive function and mental health. 1249, 118-136. https://doi.org/10.1111/j.1749-6632.2011.06400.x

Bruhn, M. (2020). Automatisierung und Personalisierung von Dienstleistungen Band 1. https://doi.org/10.1007/978-3-658-30168-2

Cheow, V., Yeo, S., Goh, S., \& Rezaei, S. (2017). Consumer experiences , attitude and behavioral intention toward online food delivery ( OFD ) services. Journal of Retailing and Consumer Services, 35(July 2016), 150-162. https://doi.org/10.1016/j.jretconser.2016.12.013

Chetioui, Y., Abbar, H., \& Benabbou, Z. (2017). The Impact of CRM dimensions on Customer Retention in the Hospitality Industry: Evidence from the Moroccan Hotel sector. Journal of Research in Marketing, 8(1), 652-660. https://doi.org/10.17722/jorm.v8i1.211

Chin, W. W. (1998). Modern Methods for Business Research. Modern Methods for Business Research. https://doi.org/10.4324/9781410604385

Drucker, P. F. (1985). The practice of entrepreneurship. Innovation and Entrepreneurship Practice and Principles, Harper \& Row, New York, pp.141-188.

Filimonau, V., \& Krivcova, M. (2017). Restaurant menu design and more responsible consumer food choice: An exploratory study of managerial perceptions. Journal of Cleaner 
Production. https://doi.org/10.1016/j.jclepro.2016.12.080

Fornell, C., \& Larcker, D. F. (1981). Evaluating Structural Equation Models with Unobservable Variables and Measurement Error. Экономика Региона, 18(August), 32. https://doi.org/10.2307/3151312

Garrido-moreno, A., \& Padilla-meléndez, A. (2011). Analyzing the impact of knowledge management on CRM success: The mediating effects of organizational factors. International $\begin{array}{llll}\text { Journal of Information } & \text { Management, } & 31(5),\end{array}$ https://doi.org/10.1016/j.ijinfomgt.2011.01.002

González Porras, J. L., Ruiz-Alba, J. L., \& Guzmán Parra, V. (2018). Customer orientation of service employees in family businesses in the hotel sector, 73-85. https://doi.org///dx.doi.org/10.17561/ree.v2018n2.4

Hafeez, M. H., \& Basheer, M. F. (2018). Exploring the Links between TQM Practices , Business Innovativeness and Firm Performance: An Emerging Market Perspective Abstract. Pakistan Journal of Social Sciences, 38(2), 485-500.

Hair Jr, J. F., Hult, G. T. M., Ringle, C., \& Sarstedt, M. (2017). A primer on partial least squares structural equation modeling (PLS-SEM). Sage Publications. https://doi.org/10.15358/9783800653614

Hardjono, B., \& San, L. P. (2017). Customer Relationship Management Implementation and its Implication to Customer Loyalty in Hospitality Industry. Jurnal Dinamika Manajemen, 8(36), 92-107. https://doi.org/10.15294/jdm.v8i1.10414

Henseler, J., Ringle, C. M., \& Sinkovics, R. R. (2009). The use of partial least squares path modeling in international marketing. Advances in International Marketing, 20(2009), 277-319. https://doi.org/10.1108/S1474-7979(2009)0000020014

Ikhsan, R. B. (2016). Impact of relationship marketing, service quality and customer orientation of service employees on customer satisfaction and behavioral intentions and its impact on customer retention. International Journal of Economics, Commerce and Management, IV(February 2017), 151-163. https://doi.org/10.13140/RG.2.2.29318.57920

Ikhsan, R. B., Prabowo, H., Wiharja, C. K., \& Vional. (2018). Customer retention as a result of behavioural intention: Relationship between customer orientation of service employee and service quality. Pertanika Journal of Social Sciences and Humanities, 26(T), 243-252.

Islamgaleyev, A., Petrova, M., Kurenkeyeva, G., Shalbayeva, S., \& Kadirbergenova, A. (2020). INCREASING CUSTOMER FOCUS IN METAL TRADING. ENTREPRENEURSHIP AND SUSTAINABILITY ISSUES, 8(1), 604-617. https://doi.org/10.9770/jesi.2020.8.1(42)

Jin, X., Lian, J. S., Hu, J. H., Gao, J., Zheng, L., Zhang, Y. M., ... Yang, Y. (2020). Epidemiological, clinical and virological characteristics of 74 cases of coronavirus-infected 
disease 2019 (COVID-19) with gastrointestinal symptoms. Gut, 69(6), 1002-1009. https://doi.org/10.1136/gutjnl-2020-320926

Kanwal, N., Farooq, M., Raju, V., Anjum, T., \& Zreen, A. (2020). Intrapreneurial Behaviour of Employees in the Era of Transformative Marketing: A Multidisciplinary Approach. International Journal of Innovation, Creativity and Change, 13(6), 1337-1353.

Kim, H., \& Lee, Y. (2020). A structural model of customer relationship management (CRM) strategies, rapport, and learner intentions in lifelong education. Asia Pacific Education Review, 21(1), 39-48. https://doi.org/10.1007/s12564-019-09583-3

Kusmintarti, A., \& Asdani, A. (2017). The relationship between creativity, entrepreneurial attitude and entrepreneurial intention ( case study on the students of State Polytechnic Malang ) The relationship between creativity, entrepreneurial attitude and entrepreneurial intention ( case stu. (July). https://doi.org/10.1504/IJTGM.2017.082379

Lambert, D. M., \& Enz, M. G. (2016). Industrial Marketing Management Issues in Supply Chain Management: Progress and potential. Industrial Marketing Management. https://doi.org/10.1016/j.indmarman.2016.12.002

Lehrer, C., Wieneke, A., Brocke, J., Jung, R., Lehrer, C., Wieneke, A., ... Vom, J. A. N. (2018). How Big Data Analytics Enables Service Innovation: Materiality , Affordance , and the Individualization of Service. Journal of Management Information Systems, 35(2), 424-460. https://doi.org/10.1080/07421222.2018.1451953

Liljander, V., Roos, I., Liljander, V., \& Roos, I. (2002). Customer-relationship levels from spurious to true relationships. Journal of Services Marketing, 16(7). https://doi.org/10.1108/08876040210447333

Mady, S. A. (2020). The Effect of Entrepreneurial and Customer Orientation on Service Quality in Hotels. Technology Reports of Kansai University, 62(06), 3025-3056.

Mau, S., Pletikosa, I., Wagner, J., \& Mau, S. (2018). Forecasting the next likely purchase events of insurance customers A case study on the value of data-rich multichannel environments. International Journal of Bank Marketing. https://doi.org/10.1108/IJBM-11-2016-0180

Miao, R., Zhang, H., Wu, Q., Zhang, J., \& Jiang, Z. (2019). Using structural equation modeling to analyze patient value, satisfaction, and loyalty: a case study of healthcare in China. International Journal of Production Research. https://doi.org/10.1080/00207543.2019.1598595

Moghadam, M. (2013). Determinants of Customer Retention: Offering a Model to Banking Industry. Journal of Applied Business and Finance Researches, 2(3), 76-81.

Nazar, N., Jahan, S., Amoozegar, A., Anjum, T., \& Raju, V. (2020). The Effects of Total Quality Management Practices on Corporate Social Responsibility using Supply Chain Model: 
A Review of Malaysian Hotel Industry. International Journal of Supply Chain Management, 9(5), 294-304.

Nazar, N., Ramzani, D. S. R., \& Temoor Anjum, I. A. S. (2018a). Organizational Performance: The Role of TQM Practices in Banking Sector of Pakistan. European Scientific Journal, 14(31), 278-302. https://doi.org/10.19044/esj.2018.v14n31p278

Nazar, N., Ramzani, S. R., \& Temoor Anjum, I. A. S. (2018b). Impact of Entrepreneurial Orientation on Bank Performance in Pakistan. Business Management and Strategy, 9(1), 290-309. https://doi.org/10.5296/bms.v9i1.13212

Ng, S. C., Sweeney, J. C., \& Plewa, C. (2020). Customer engagement: A systematic review and future research priorities. Australasian Marketing Journal (AMJ), (xxxx). https://doi.org/10.1016/j.ausmj.2020.05.004

Ngetich, K. (2018). Effect of funds disbursement procedures on public procurement performance in nyeri county: ( a case of nyeri sub- county ). International Journal of Recent Research in Social Sciences and Humanities, 5(4), 107-112.

Qi, J. M., Wang, S., \& Koerber, M. A. (2020). When do frontline service employees feel more grateful? employees. European Journal of Marketing. https://doi.org/10.1108/EJM-06-2019-0496

Rahi, S. (2016). Impact of Customer Value, Public Relations Perception and Brand Image on Customer Loyalty in Services Sector of Pakistan. Arabian Journal of Business and Ar A Management Review, S2(004). https://doi.org/10.4172/2223-5833.S2-004

Rakthin, S., Calantone, R. J., \& Feng, J. (2016). Managing market intelligence: The comparative role of absorptive capacity and market orientation. Journal of Business Research. https://doi.org/10.1016/j.jbusres.2016.03.064

Rao, T. A., Raju, D. V., \& Anjum, T. (2020). A Mediating Role of Adaptive Selling Behavior: Relationship between Emotional Intelligence and Sales Performance. Beverage Industry of Pakistan. International Journal of Psychosocial Rehabilitation, 24(1), 5266-5275.

Rather, R. A., \& Sharma, J. (2017). The effects of customer satisfaction and commitment on customer loyalty: evidence from the hotel industry. Journal of Hospitality Application \& Research, 12(2).

Rouholamini, M., \& Alizadeh, R. (2016). A Study of Customer Orientation in the Iranian Banking Industry: The Case of Mellat Bank. International Journal of Research in Management, Economics and Commerce, 06(06), 50-55.

Shapiro, C. (2019). Protecting Competition in the American Economy: Merger Control, Tech Titans, Labor Markets. Journal of Economic Perspectives, 33(3), 69-93. https://doi.org/10.1257/jep.33.3.69

Singh, J., Flaherty, K., Sohi, R. S., Deeter-schmelz, D., Habel, J., Meunier-fitzhugh, K. Le, ... 


\section{Macrothink

Mullins, R. (2019). Sales profession and professionals in the age of digitization and artificial intelligence technologies: concepts, priorities, and questions. Journal of Personal Selling \& Sales Management, O(0), 1-21. https://doi.org/10.1080/08853134.2018.1557525

Suraj, M. (2016). Customer Retention Strategies Adopted by Standalone Restaurants in Pune and Its Benefit to the Restaurant. Journal of Hospitality, 2(2).

Thaichon, P., Liyanaarachchi, G., Quach, S., \& Weaven, S. (2019). Online relationship marketing: evolution and theoretical insights into online relationship marketing marketing. Marketing Intelligence \& Planning. https://doi.org/10.1108/MIP-04-2019-0232

Torabi, F., \& El-Den, J. (2017). The impact of Knowledge Management on Organizational Productivity: A Case Study on Koosar Bank of Iran. Procedia Computer Science, 124, 300-310. https://doi.org/10.1016/j.procs.2017.12.159

Umashankar, N., Bhagwat, Y., \& Kumar, V. (2016). Do loyal customers really pay more for services? Journal of the Academy of Marketing Science, 45(6), 807-826. https://doi.org/10.1007/s11747-016-0491-8

Valens, S., Grace, U. M., \& Alphonse, H. (2020). Assessment of the practices of direct marketing tools on customer awareness and business performance: a case of konka group company 1td. European Journal of Management and Marketing Studies, 25-50. https://doi.org/10.5281/zenodo.3627407

Xing, L., \& Devasia, S. N. (2019). The Influence of Customer Relationship Management on Customer Retention in the Insurance Sector, Malaysia. INTI JOURNAL, 2019(September).

Yeh, J. H., Wang, S. W., Hsu, M. K., Swanson, S., He, J., Wang, S. W., ... Key, S. S. (2017). Key account relationship management: the moderating effects of relationship duration and transaction volume. The Service Industries Journal, O(0), 1-23. https://doi.org/10.1080/02642069.2017.1393524

\section{Copyright}

Copyright for this article is retained by the author(s), with first publication rights granted to the journal.

This is an open-access article distributed under the terms and conditions of the Creative Commons Attribution license (http://creativecommons.org/licenses/by/4.0/). 